\section{The process of redrawing as an instrument of knowledge buil- ding in architecture}

Ana Gabriela Godinho Lima, Júlio Luiz Vieira

\section{Ana Gabriela Godinho Lima}

$\mathrm{PhD}$ in Architecture and Urbanism; Teacher and researcher at 'Faculdade de Arquitetura e Urbanismo' in 'Universidade Mackenzie' and at 'PPG-FAUMACK'; anagabriela.lima@mackenzie.br

\section{Júlio Luiz Vieira}

$\mathrm{PhD}$ in Architecture and Urbanism; Teacher and researcher at 'Faculdade de Arquitetura e Urbanismo' in 'Universidade Mackenzie'; julio.vieira@mackenzie.br

\begin{abstract}
This communication examines the redrawing role as instrument of knowledge building in academic research in areas of design practice. It structure is two folded: the first part deals with the theoretical foundation which has been built through research projects with which the authors had took part in. It points out the development and the operation of two indicators in the assessment of academic research in areas of design practice: the historic/historiographical indicator and the design indicator. The second part is dedicated to one of the authors doctoral research analysis. It proceeds to the verification of how the indicators may be operated regarding the investigation strategies adopted. The discussion focus is adjusted on the redrawing as a fundamental strategy in building knowledge in architecture. It also takes into account that the redrawing activity is always historically situated.
\end{abstract}

Keywords: Graphic resources. Research. Architectural Historiography. Academic Research.

\section{Resumo}

Esta comunicação examina o papel do redesenho como instrumento de construção de conhecimento na pesquisa acadêmica em arquitetura. Para tanto estrutura-se em duas partes: a primeira dá conta do suporte teórico construído ao longo do desenvolvimento de projetos de pesquisa em que os autores estiveram engajados, apontando para a formulação e emprego de dois indicadores de avaliação da pesquisa acadêmica em áreas de prática projetual - 0 indicador histórico/historiográfico e o indicador projetual. A segunda parte detém-se na análise da tese de doutoramento de um dos autores, procedendo à verificação da operação dos indicadores enunciados nas estratégias de investigação adotadas. O foco da argumentação recai sobre o redesenho como estratégia projetual fundamental na construção do conhecimento na pesquisa em arquitetura. Tem ainda em vista que a atividade de redesenhar é sempre situada historicamente.

Palavras-chave: Recursos gráficos. Pesquisa. Historiografia arquitetônica. Pesquisa Acadêmica

\section{Resumen}

Este artículo examina el papel del rediseño como herramienta de construcción de conocimiento en la investigación académica en la arquitectura. Para tanto se estructura en dos partes: la primera presenta una relación de apoyo teórico construído sobre el desarrollo de proyectos de investigación a la que se dedicaban los 
autores, que apunta a la preparación y la utilización de dos indicadores de evaluación de la investigación académica en las áreas de práctica proyectual - un indicador histórico / historiográfico y outro proyectual. La segunda parte consiste en la análisis de la tesis doctoral de uno de los autores, procediendo a verificar el funcionamiento de los indicadores establecidos en las estrategias de investigación adoptadas. El enfoque del argumento se basa en el rediseño como estrategia proyectual fundamental en la construcción del conocimiento en la investigación de la arquitectura. Además, considera que la actividad de rediseñar se sitúa siempre históricamente.

Palavras-clave: Capacidades graficas. Investigación. La historiografía arquitectónica. La investigación académica.

\section{Introduction}

$\mathbf{T}$ he purpose of this paper is to analyze and describe, according to the rigorous terms of the academic research, the essential characteristics about the role of redrawing instruments in architectural design research.

The founding framework of the theoretical analysis undertaken here is the project "Pesquisa Acadêmica em Áreas de Prática Projetual: Arquitetura e Urbanismo" PAAPP, (LIMA et. al. 2011) research report, whose results include publications and the development of PhD and Master's researches, as well as Final Graduation Works. Among these, we highlight some publications, such as "Proyectos e Métodos proyectuales en La Investigación Académica: Algunos indicadores útiles" (LIMA and ZEIN, 2011), which discusses the constant presence and the relationship between what we call, on one hand, historical and historiographic indicators, and, on the other hand, the design-based indicators in academic investigation in areas of practice-based research. Indeed, the fact that these indicators, one textual (historical and historiographic) and one graphic (design), can be very effective in the acknowledgement and assessment of academic research in design areas, and this is one of the main PAAPP results.

The evidences about the relevance in considering these indicators not only as an aid in the acknowledgement and assessment of the research that relies on design methods (such as redrawing) for the construction of the argumentation, but also as a useful tool in the process of conducting research, can be found in publications, guidelines and academic dialogues that followed the previous project. Among these repercussions it is necessary to mention at least two articles. The first, "Proyectos, teorias e investigación: tendencias de la enseñanza en arquitectura y urbanismo." (LIMA et. al. 2011), incorporates some elements about the relationship between the modes of production of historical and 
projective knowledge in the reflection on teaching and researching in architecture and urbanism within the stricto sensu postgraduate programs.

In "Indicadores de Pesquisa Acadêmica em Áreas de Prática Projetual" (LIMA et. al., 2011), the authors continued from the last article, published the same year by Lima and Zein, proposing some unfolding in the use of the historical / historiographic and design-based indicators, in the meanings of the structures of the practice-based research. Therefore, it is important to describe, although succinctly, the two indicators mentioned above, historical and design, and the procedures adopted to establish them. Let's start with the procedures:

Based on bibliographic review and discussions among the members of the research team ${ }^{1}$, initial delimitations has been established regarding the elements that are part of what we call "design practice", and how they could be identified in academic research;

As a result, initial arguments were constructed about the characteristics effectively found in architecture and urbanism theses and dissertations that employ elements of the architectural project as an essential part of its argumentation. However, it was not possible to propose the existence of evident differences in relation to the traditional methods of research. What was observed was the effective association between traditional methods, especially historical / historiographic, and design methods. What has been achieved consisted in clearly establishing two indicators that characterize the research that make use of design methods as a fundamental part of its argument.

\section{Design-based:}

The use of design methods, as employed in the universe of works analyzed, suggests approximations with the notion of artifact, that is, they appear to constitute of non-textual constructions that aim to bring to the surface an element of the problematic involved in the work that would not be capable of description or understanding by traditional textual methods.

The conceptual construction of this indicator aims to allow the identification and legitimation of theses and dissertations that, using non-textual methods, the socalled non-textual artifacts, imply that the process of methodological decisions and the contextualization and solution of the problem can be clearly described. Or, they could answer the following question of Scrieven-
${ }^{1}$ Research team of "Pesquisa Acadêmica em Áreas de Prática Projetual": Prof. Ana Gabriela Godinho Lima, Ph.D. (leader), Prof. Rafael Perrone, Ph.D., Prof. Ruth Verde Zein, Ph.D., Prof. Cecília Rodrigues dos Santos, Ph.D., Prof. Maria Isabel Villac, Ph.D., Prof. Angelo Cecco. Students: Agnes del Comune, Maryellen Sanchez, Matheus Vasconcellos, Funding: "Fundo Mackenzie de Pesquisa - Mackpesquisa". 
er (2000): has the researcher "demonstrated to be aware of what one was doing and was shown to be able to propose and to solve problems", and, we add here, by means of the use of non-textuals artifacts?

\section{Historical / Historiographic:}

Using historical or historiographical (textual) methods, that contextualize, justify and situate the concern of design imprint. What was observed was the use of historical / historiographical methods in order to locate more accurately the cultural context, the topics, and the cultural concerns and interests relevant to the topics discussed. These methods seem to align with the methods adopted for academic research in the areas of architecture and urbanism in Europe and the USA. This impression is corroborated by the work of Borden and Ray, The Dissertation: an architecture student's handbook (2009). The authors agree that academic research in architecture and urbanism can take very different characteristics and that there is no consensus as to which particular form or forms this type of research should take. Emphasizing the most commonly accepted aspects of academic research, such as the need for originality, assumed by the researcher himself / herself and the acknowledgement of the ideas and works of other authors when appropriate. This acknowledgement, in our view, goes through the connections that the researcher builds between his / her work, and the historically established and organized knowledge.

The conclusions reached by the 2011 report reflected the relevance of establishing these indicators. For the team, this was mainly located in the contribution to the acknowledgement and credibility of master's and doctoral theses that employ non-textual artifacts as a means, method and / or research topic. In subsequent years, explorations of these results took place.

Among these, it is worth mentioning briefly the project entitled "Práticas Projetuais: práticas de projeto de arquitetas, arquitetos e designers: análise dos instrumentos de prática projetual e possíveis empregos, de

2 Funding "Fundo Mackenzie de Pesquisa: Mackpesquisa". forma direta ou não - na pesquisa acadêmica stricto sensu" (2012/2014)2. It was dedicated to the investigation of the design practices in architecture, urbanism and design, in order to identify and describe the ways by which they can be used as a way of building academic knowledge. Design instruments including sketches, preliminary studies, construction of physical and virtual models, plants, cuts and elevations - in study versions and technically represented versions - 
in addition to photographic and visual studies, make up the usual practice of architecture and urbanism. However, when used as a procedure for the construction of academic knowledge in doctoral theses, master's dissertations and even scientific initiation research, they face some problematic aspects.

The main problem addressed was the identification and description of the relationships between professional practices in architecture and urban design and the conceptions and implications involved when the researcher engages in academic research, notably doctoral theses, master's dissertations and scientific initiations, in architectural design and urbanism. The project aimed to formulate statements that contributed to the literature to counselors, members of examining boards and members of research promotion agencies. The counselor, for example, may find it useful to have clear statements that contemplate the Brazilian context, on topics such as: 1 . ways of approach to conventional literature versus other sources more specific to the project; 2 . strategies of argument construction; 3 . valid research methodologies using design methods; 4 . demonstration and clear communication.

The initial conclusions indicate, in one hand, that the habitual practices of the doing and thinking of the professional life are deeply challenged throughout the process of construction the dissertation or thesis, especially regarding to the elaboration of the academic text. On the other hand, aspects such as intuition about the correct path to follow, strategies for work organization and, mainly, visual resources, such as the use of photographs, maps, reproduction of drawings and the redraw were the essential elements in the construction of the argumentation and work development.

We understand that these results corroborate the validity of the two indicators mentioned above: historical/historiographic and design-based. Regarding the historical indicator, we verified its relevance in the examination of the following aspects of the surveys forwarded by the professionals interviewed:

- delimitation of the research cut-off;

- selection of bibliography to be reviewed;

- establishing the theoretical framework;

- development of analyzes. 
Each of these aspects is guided by historical / historiographic elements. It should be noted, however, that the researchers elaborate bibliographical selections and theoretical references in a way more guided by authors and publications valued throughout undergraduate teaching and postgraduate classes and in conversations with the advisors, than by a methodological construction, based in current historiographical trends. In other words, the researcher can often use, in the same analysis, authors of different currents of thought, without feeling the need to explain, in his or her argument, the reason for the articulation of arguments coming from authors that are often considered antagonistic or whose perspectives seem incompatible.

In this article context, it is not possible to discuss the validity or not of methodological operations of this nature, but rather to point out that it may be desirable to strengthen the debate in order to discuss the convenience of being more explicit about the historiographical approaches, effectively employed in the practice-based research.

historiographical approaches, effectively employed in the practice-based research.

The use of the design-based indicator allows us to focus on work strategies whose main reason is the experience acquired during the professional practice. Regarding this indicator, it is interesting to note what we consider to be the overlapping areas with the historical / historiographic indicator. This particularly occur in the selection of works and authors, which, for experienced practitioners, tends to be an option guided by readings during training periods, professional updating readings and also an identification of buildings and professionals that have peer recognition in the professional environment.

In any case, the main aspects evaluated by this indicator are those related to the elaboration of physical models, maps, plans, cuts, façades, elevations, schemes, sketches. Also, the selection and organization of photographs in the pages that compose the work are carried out based on the experience acquired over the years of professional practice. In this set, the redrawing instruments are adopted as a privileged strategy in the construction and explanation of the understandings arising from the analysis undertaken in the context of the research.

The work we choose here for analysis illustrates specific aspects of the use of redrawing as a tool, built on 
the author's design practice, as we shall see later. For now, we stop at some considerations that seem appropriate to describe, to some degree, how indicators can be managed in the analysis of academic papers.

\section{Identification and verification of historical / historiographic and design-based indicators in academic research}

Once the above indicators are outlined and described, the question is: how to effectively identify, describe, and analyze their use in academic research that employs tools of design practice, such as redrawing instruments, as an essential part of building an argumentation?

First of all, as we have said, it is necessary to have in mind that all intellectual, textual and non-textual construction is situated within a historically constructed disciplinary field, and it is in this context that we use the historical / historiographic indicator first, in order to verify the researcher historical position, be it explicit or not.

\section{Historical/historiographic indicator verification}

The history, historiography and bibliography of architecture have, in this context, an important role in giving meaning to architectural production, organizing architectural productions, designers and places on specific value scales. Being taught part in the form of text, part in the form of images, the history of architecture has an important effect in creating a sense of reality that students mentally build. As Marina Waisman (2009) ponders, while the historical problems refer to the existence of the historical fact - its likelihood, the date, the author, the circumstances of its production - the historiographical problems directly compromise the historian's ideology, implied in the selection of the object of study, of its critical instruments, of the structure of the text and "all that will lead to the interpretation of the meaning of the facts and, ultimately, to the formulation of its version of the chosen theme" (Waisman, 2009, p. 15).

With this in view, the examination of the historical / historiographic indicator requires, by the examiner, some previous knowledge about the main historiographic currents used in the academic research in architecture and urbanism. Borden and Ray (2009) compile, at international level, the historiographical tendencies 
most commonly used in this field of research: empiricism; iconography; history and hegelian theory; social history; history and political theory; operative history and theory; theoretical and interdisciplinary studies; social sciences; personal writing; studies based on visual analysis.

\section{Design-based indicator verification}

Would the verification of the design-based indicator in practice-based researches call for an examiner who would necessarily have experience in the architectural practice? This is certainly a point that deserves careful reflection and debate. What can be said, of course, is that it is necessary that the examiner is aware of the debate on the research in this field and its essential characteristics. As Doris Kowaltowsky reminds us, in her presentation to the Brazilian edition of Bryan Lawson's book "Como Arquitetos e Designers pensam" (2011), it was the English researcher Nigel Cross, one of the founders of the journal Design Studies who identified the main issues discussed about the design methods:

1. control of the design process;

2. the structure of the design problems;

3. the nature of the project activity;

4. the philosophy of the design method.

The measurement of the design-based indicator could pass, at the examiner's discretion, through an initial stage in which it is verified whether, in fact, the work in question is characterized as a practice-based research. This would imply the presence of two elements:

1) the construction of the central argumentation of the work, necessarily involves the use of design tools, in other words, it does not dispense the design and graphic elements for its construction and demonstration, and 2 ) it is framed in a broader context of academic debate, such as the four strands listed above, or possibly others that are in action. This would ensure that it is in academic level research, and not of a technical nature, whose purposes are, of course, very different.

Once verified the adequacy of the research to the themes related to the design practice, the verification would then examine the construction and demonstration of the arguments, with emphasis on the process, but not losing sight of the results achieved at the end. From the process point of view, it is important to analyze the presence of non-textual elements in at least 
three angles: the goal statement that indicates the need to use graphic elements to achieve it; the way graphical resources were built to achieve the goal; the ability demonstrated in the presentation of the graphical elements elaborated in this way. From the point of view of the final product, the answer to three essential questions can contribute to a more accurate examination (LIMA et al., 2011):

Does the paper clearly present the problem characterization and the use of graphic elements is the most appropriate solution to answer it?

It is possible to clearly demonstrate or verify that the use of graphic elements was the most appropriate solution to solve the problem?

Can the use of the adopted solution be communicated collectively and benefit other researchers who encounter similar problems?

In summary, the topics that make up this indicator aim to contribute to the identification, acknowledgement and assessment of academic research that, by using graphical methods, such as redrawing, builds a type of knowledge that could not be reached in another way. In this paper, we reflect specifically on how the practice of redrawing constitutes an essential tool for the development of the construction of historical and historiographic knowledge in architecture. In order to substantiate the first part of this work, in which we propose the definition of two indicators of analysis for practice-based research, in the second part, we discuss a specific research, a doctoral thesis, in which the elements discussed in the first part appear as strategy of execution of the work and resource for a posteriori reflection on the results reached to its end.

\section{Rebuilding a research route: vias of approaching for reading the spatial condition in architecture}

\section{Building an approach through redrawing}

In the realm of architecture criticism or historiographic research, redrawing architectural works, either built or not, represents a resource whose power of clarifying the spatial qualities of a building can not be replaced by textual descriptions. This is one of the assumptions in the thesis 'Vias of approaching for Reading the Spa- 
tial Condition in Architecture' (2015), which aimed to draw an approaching strategy to the 'reading' of spatial qualities in architectural works by making use of graphical elements derived from graphical documentation of selected works.

The spatial qualities having the power of determining vital experiences for human beings in their environment, when taken as whole, will characterize a particular condition, a nature, a feature of the spaces in architecture. Some thing that would allow to define it as a spatial organism bearing an identity trait, and help to individualize it as a phenomenon while at the same time aiding to trace its historical lineage.

Redrawing the works aiming specifically to visualize that 'spatial condition' referred above did require specific tools. It was necessary to work on the 'original' drawings, aiming to create 'filters' suitable for the information looked for relating to the spatial concepts listed for the readings.

It is worth pointing out that such 'interventions' in the original drawings allowed to make explicit certain hidden 'spatial values', thus constituing an essential device to subsequent comparisons. Even though the study was centered on public or semipublic urban buildings, the method employed is considered to be equally applicable to other types of buildings, while adjustments to the set of observable concepts might be needed.

In the specific case of the mentioned thesis, each reading was intended to capture aspects of the architectural spatiality that allowed to identify its particular nature. Each applied concept corresponded to a spatial aspect sought to be understood.

The historic/historiographic indicator is represented by the literature selected to build a conceptual thematic framework for the readings, which was established according to the objectivity of the approach employed, regarded as having a significant effectiveness/operativeness degree.

Standing out in this group are the works by Herman Hertzberger (2006 e 2010), Bernard Leupen (1999) and Simon Unwin (2003), all of them contemporary architects devoted to the analytical study of architecture who apply methods that use work iconographies and design redrawings in order to emphasize particular aspects of spatial study. They also share ideological affinities in that they incorporate in their analyses revisionist views about the modern ideology charac- 
teristic of the first years of the 20th century. Notably, these authors incorporate in their analyses debates that only became frequent in the field of architecture criticism in the $1950 \mathrm{~s}$, e.g. about the role of surrounding physical context in determining the architectural project premise, or of the concept of "place", or existential space, in the understanding and retrieving of traditional city's urban qualities to the way of thinking on the contemporary urban space.

Design-based indicators are represented by the collection of concepts which the core reflections in this work are based on. Concepts chosen to create a thematic framework for the readings were primarily derived from a systematic thought developed over years practicing and teaching architectural project, and rested upon a humanist view rooted in the tradition established by Ernesto Nathan Rogers (apud Montaner, 2002), who deemed architecture to be the major integrating piece in actions to restore the urban space, which should necessarily start from existing real conditions and leave behind the international-style uniformizing models. An existentialist approach to urban space is also present in the work of Christian Norberg-Schulz (1975), who resorts to the definition of genius loci (or the spirit of the place) to construct a concept of existential space, or simply "place", developed by using phenomenological tools and Martin Heidegger's philosophical works.

This literature review was the srtarting point for the ellaboration of seven essential analysis elements, namely, context, occupation, permeability, sociability, flows, stratification, and structure. This thematic framework was named in the work as 'vias of approaching', suggesting the idea of a 'path', or 'means'.

\section{Seven vias of approaching: redrawing strategies ${ }^{3}$}

This thematic framework was named in the work as 'vias of approaching', suggesting the idea of a 'path', or 'means'. The sequential organization of these 'vias of approaching' meets a criterion that emulates a route drawn from general to specific, from major to minor scale, hence beginning with the item addressing the relations of architecture with its physical context, and then, gradually turning toward objects' inner part. In a certain way, it also seeks to replicate the steps in architectural project process, evoking a making-decision process.
${ }^{3}$ The other English versions originally used for the term "via" are divided into "routes" and "ways". In the original version of the thesis under analysis, the term "ways" was used in the English version of the abstract and in the title itself, as can be seen in the database of the Thesis and Dissertations Library of the University of São Paulo. 


\section{First via: context}

The via corresponding to 'context' has as strategy to compare geometries in the perimeter of the built assemblage (in plan and elevation) with two-dimensional geometries in the built masses/volumes that constitute the immediate surroundings.

In the first diagram [Figure 01], a location plan with aerial photo background highlights the profile of the built mass/volume projection on the ground, as well as the plot limits and the reference (parallel) lines drawn by the profile of the built volume projection. The second diagram [Figure 02] presents the same graphical elements except the photographic background for a better view of the projected shape's geometries. Built mass/volume profiles are also compared in height with surrounding buildings' profiles by means of a schematic urban elevation [Figure 03].
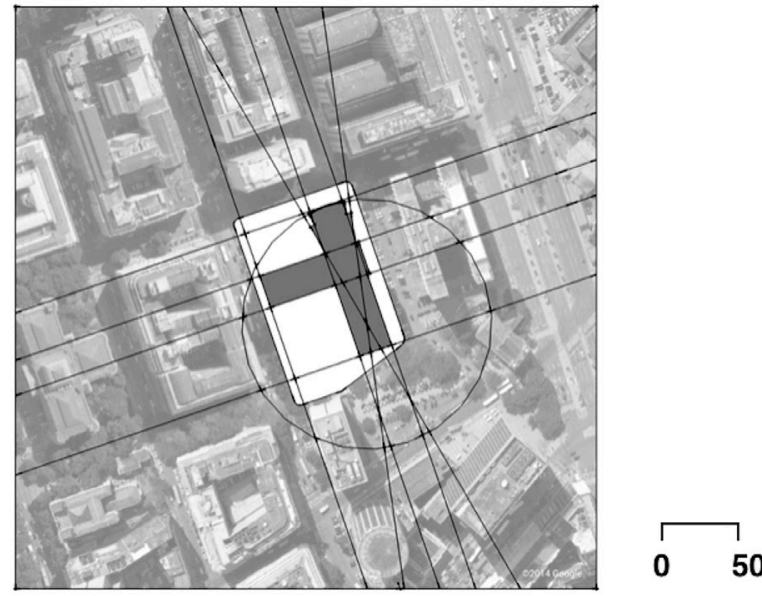

\section{Figure 01}

Department of Education and Health of Rio de Janeiro. Lucio Costa, Oscar Niemeyer and team. Location plan with aerial photo background.

Source: Vieira, 2015, p. 151.

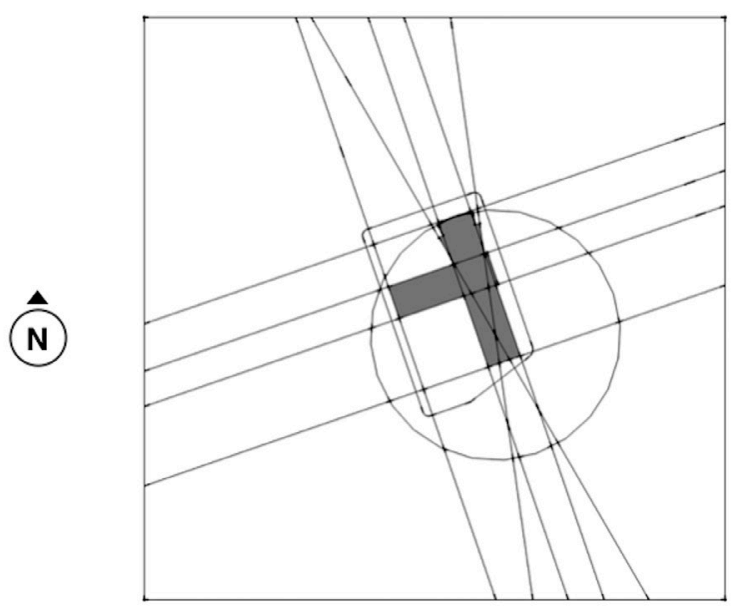

Figure 02

Department of Education and Health of Rio de Janeiro. Lucio Costa, Oscar Niemeyer and team. Location plan.

Source: Vieira, 2015, p. 151

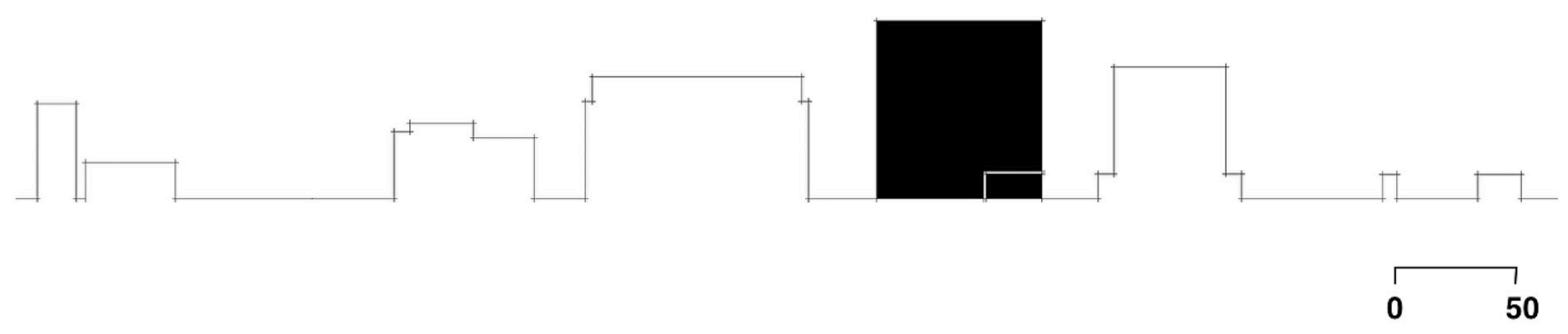

Department of Education and Health of Rio de Janeiro. Lucio Costa, Oscar Niemeyer and team. Schematic urban elevation based on data collected from Google Earth.

Source: Vieira, 2015, p. 151 
Those diagrams provide a reading of the spatial condition as determined by the geometrical relation between context and built assemblage. This relation can be established by visual ideas expressing integration, articulation, repetition, adjustment, continuity, and rupture.

\section{Second via: occupation}

To make it possible a reading of the spatial condition as determined by the morphology of the built assemblage projection on the intervention area, a set of graphical pieces was developed aiming to understand the ambivalent relations between occupation and free space geometries, between volume/mass and void.

In the site plan figure-ground diagram [Figure 04], black color (figure) represents the built assemblage projection, and thick lines, the barriers consisting of side walls and neighbour gables. In the Figure 05, a graphical synthesis of the site plan includes the usual lines outside the façade taken at each directional inflection segment. The meeting-point of two or more usual lines will indicate an arrangement of formal enclosing.

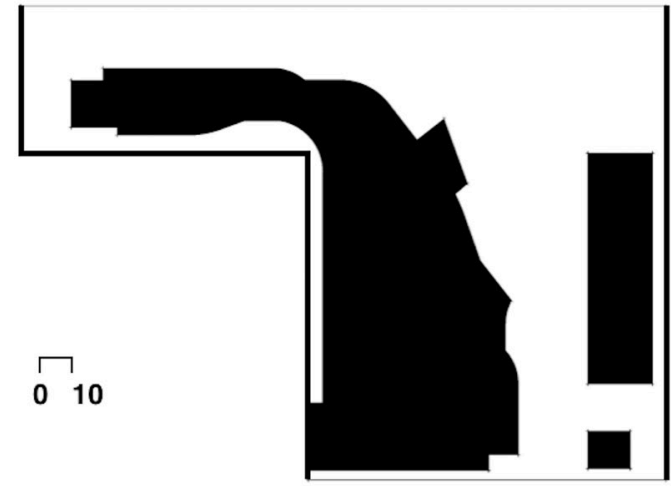

Figure 04

Maxxi Museum, Rome. Zaha Hadid.

Site plan figure-ground. Source: Vieira, 2015, p. 182.

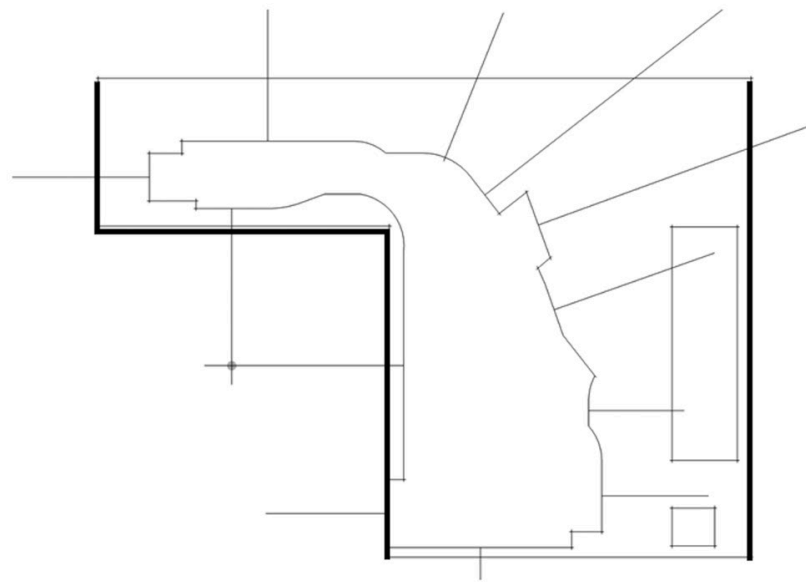

Figure 05

Maxxi Museum, Rome. Zaha Hadid. Enclosing perimeter.

Source: Vieira, 2015, p. 182

A ideia subjacente à verificação da envolvência das formas edificadas em relação aos vazios, é a de que perímetros envolventes têm mais capacidade de gerar recintos externos.

\section{Third via: permeability}

It is difficult to read spatial permeability condition in architecture without appropriate graphical tools. 
Merely observing conventional drawings does not allow to rapidly and clearly assess the gradation and characteristics of that condition. The diagram of permeability shown in the Figure 06 and drawn from the site plan (ground floor) taking as reference the plot borders, registers the main pedestrian route axes and internal and external access points. The accessibility diagram in the Figure 07 , based on the building access plan, shows accessibility gradations defined for the main access floor through gray-hued chromatic areas ranging from white (maximum accessibility) to black (minimum accessibility). The objective is to identify conditions of penetrability and route crossings, and to assess the accessibility gradation in the building access areas (both internal and external).

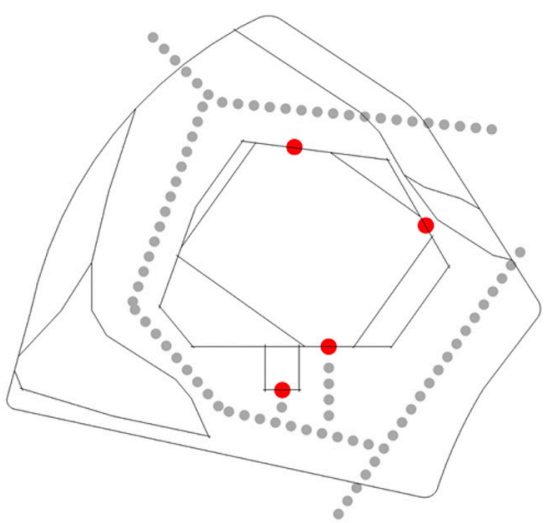

Figure 06

Casa da Música do Porto (Porto Music House), Porto. OMA. Permeability. Pedestrian routes and accesses.

Source: Vieira, 2015, p. 169.

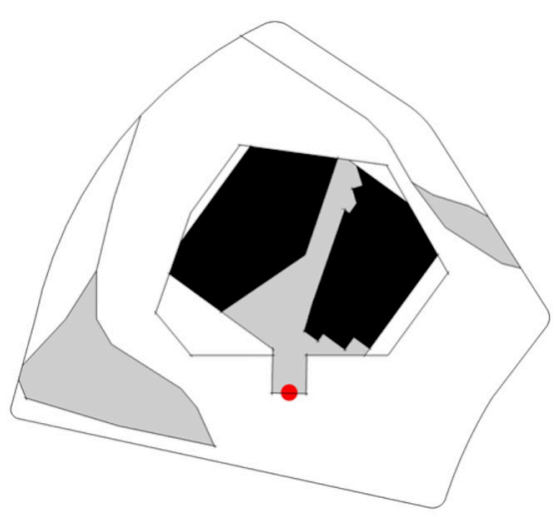

Figure 07

Casa da Música do Porto (Porto Music House), Porto. OMA. Accessibility.

Source: Vieira, 2015, p. 169

\section{Fourth via: sociability}

The use of graphical elements to read architectural spatial condition concerning space sociability aims to recognize geometrical conditions that encourage collective public use, e.g. those provided by canopies and/or marquees over freely accessible external areas.

Therefore, the objective was to identify the occurrence and geometry of 'positive space' in the external areas. The occurrence and geometry of 'sheltered spaces' outside the building also matter. 'Positive space' showed in the Figure 08 was built from the (ground-level) site plan and taking as reference the plot's borders; façade lines were lengthened to make it easy to identify and mark the 'positive spaces'. The diagram demonstrating external sheltered spaces in the Figure 09 was built 
from the (ground-level) site plan and taking as reference the plot's borders. External sheltered spaces along the buildings are delimited aiming to identify areas encouraging socializing activities.

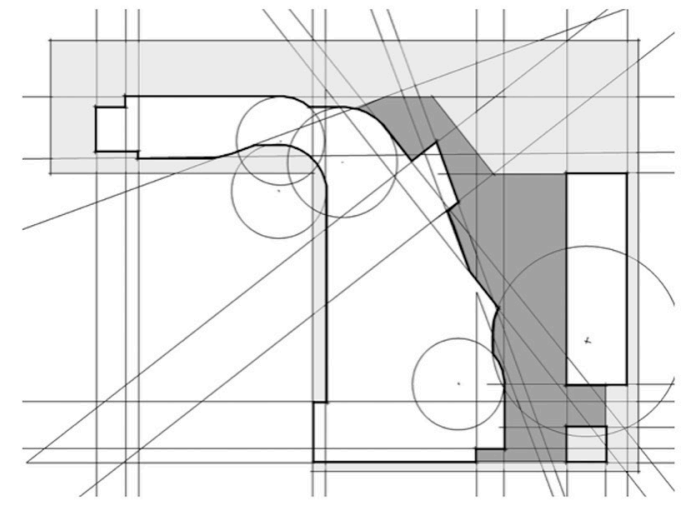

Figure 08

Maxxi Museum, Rome. Zaha Hadid. Positive space. Source: Vieira, 2015, p. 184.

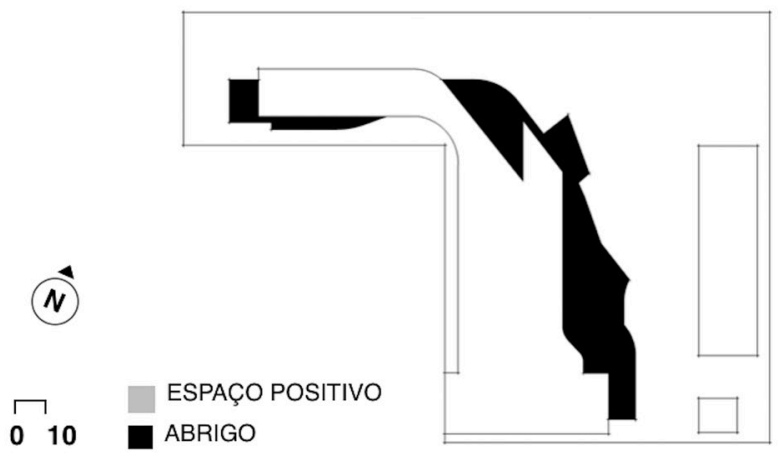

Figure 09

Maxxi Museum, Rome. Zaha Hadid. External sheltered spaces.

Source: Vieira, 2015, p. 184.

\section{Fifth via: flows}

To verify the occurrence of served and servant spaces as well as their locational and geometric characteristics is what a reading of architectural spatial condition of circulation systems is intended for. The diagram showing the ground floor's sector and flow plan [Figure 10] indicates the main circulation axes and distinguishes circulation areas (servant spaces) from use-spaces (served spaces). By estimating their areas and indicating their proportions is possible to carry out a comparative study. Figure 11 brings same information taken from higher floors.

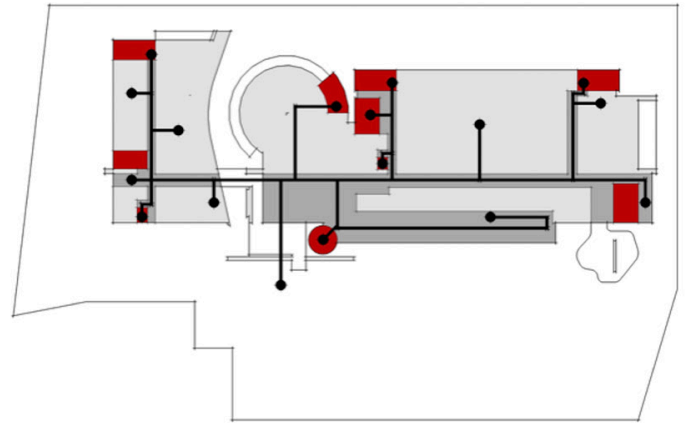

ESPAÇO-USO
CIRCULAÇÃO
NÚCLEO

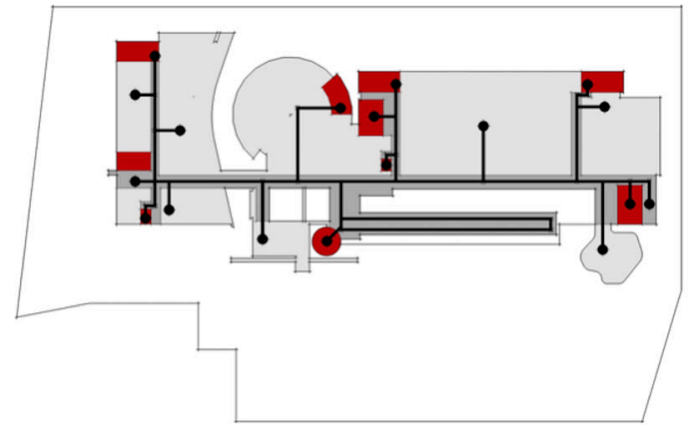

Figure 10

Barcelona Museum of Contemporary Art, Barcelona. Richard Meier. Ground floor sector and flow plan.

Source: Vieira, 2015, p. 20
Figure 11

Barcelona Museum of Contemporary Art, Barcelona. Richard Meier. Sector and flow plan of higher floors. Source: Vieira, 2015, p. 208. 


\section{Sixth via: stratification}

This via is intended to register the occurrence and geometry of vertical spaces in a building, and also to identify the spatial interaction between its strata (layers). Another objective is to verify the geometrical relation of the floors to each other, and between them and the roof. The isometric projection and its sectional view are represented in the diagrams shown in the Figures 12 and 13 which, along with the vertical spaces pointed out in the cross-sectional view [Figure 14], reveal the architectural spatial verticality.
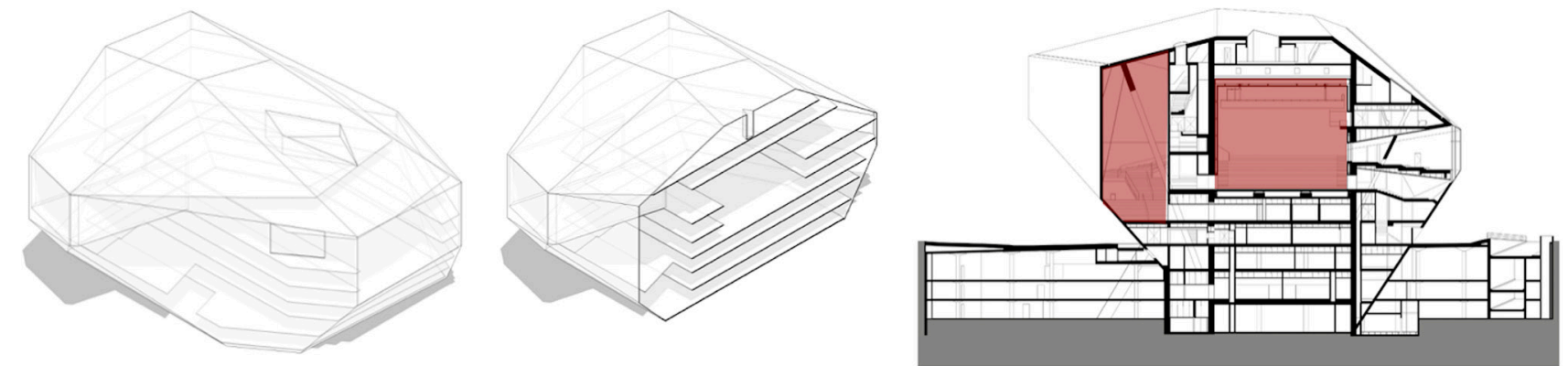

Casa da Música do Porto (Porto Music House), Porto. OMA. Left: Isometric projection of the main volume. Right: Isometric sectional view. Source: Vieira, 2015, p. 171.

\section{Figure 14}

Casa da Música do Porto (Porto Music House), Porto. OMA. Spatial verticality.

Source: Vieira, 2015, p. 172.

\section{Seventh via: structure}

The structural conception adopted in an architectural work corresponds to the final way for reading a spatial condition. The objectives here are (1) to verify the occurrence of visible structural elements and their geometric and locational characteristics, (2) to identify the features of their ordering structure, and (3) to describe the interdependent relationship between structural elements and space arrangement. The main diagram [Figure 15] highlights the chief structural axes on the ground floor plan. Sectional views [Figures 16 and 17] showing internal structural elements complete the diagrams. 


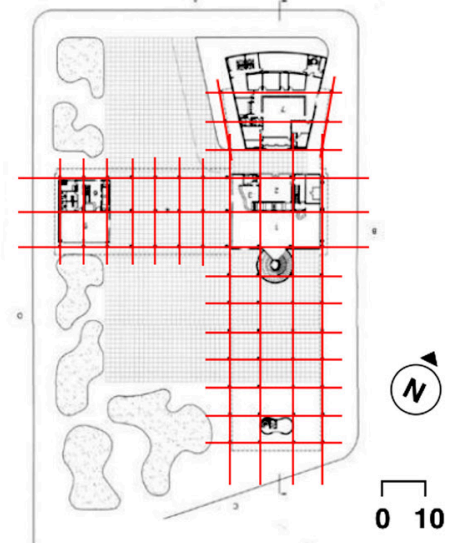

Figure 15

Department of Education and Health of Rio de Janeiro. Lucio Costa, Oscar Niemeyer and team. Ground floor plan with the main structural axes.

Source: Vieira, 2015, p. 159

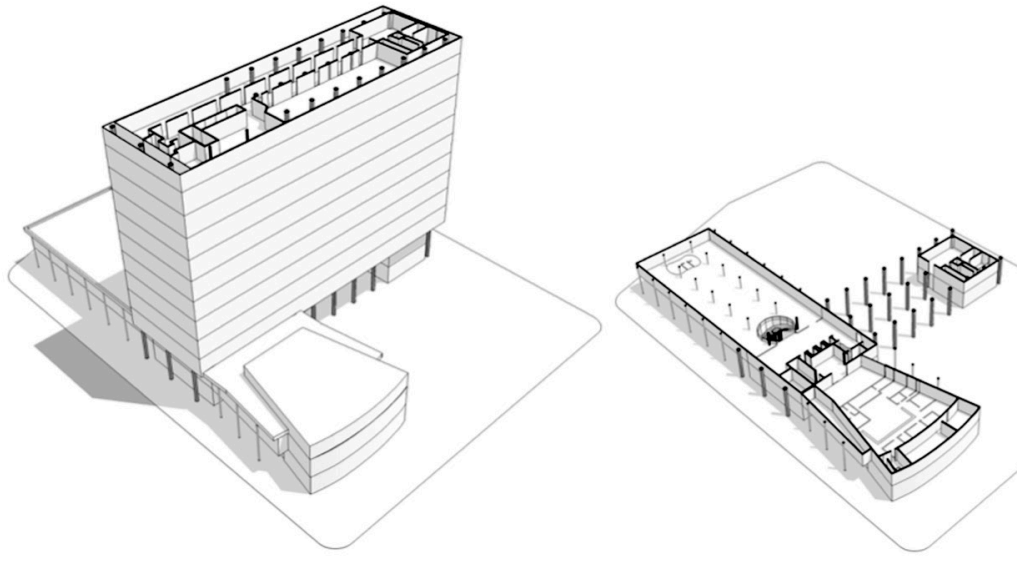

Figures 16-17

Department of Education and Health of Rio de Janeiro. Lucio Costa, Oscar Niemeyer and team. Secctional views. Source: Vieira, 2015, p. 160.

\section{Final considerations}

Picking up the thread of our discussion, in the first part of this article we presented a brief historical development regarding the research projects in practice-based areas, carried out since 2006, within the scope of the Faculty of Architecture and Urbanism of Universidade Presbiteriana Mackenzie and its partnerships. In this process, stands out the establishment of indicators for acknowledgement and analysis of academic research based in design practices - with focus on drawing and redrawing instruments - as a way of constructing the fundamental arguments in the research. The indicators are: 1.) historical/historiographic and 2.) design-based.

In the present article, which sought specifically to establish a productive dialogue from the theme of this event, the doctoral thesis of one of the authors has been examined, in an attempt to illustrate aspects on how the redrawing (which falls within the "design-based" indicator) is a way of constructing knowledge whose structure emerges from a historical / historiographic root. As it may have been possible to observe, the practice of redrawing implies the construction of a specific view, built on architectural values whose specific weight is given by historical / historiographic studies, but whose characteristics can only be known through the images. In the case of the work examined here, by means of approaches built through redrawing instruments. 
One of the important aspects in the elaboration of the method proposed by Vieira (2015), resided in the approach by successive approximations, that purposely evoked the process of design in architecture. In this sense, the elements that appear redesigned also consist in metalinguistic practice, since they consist in the construction of a discourse, although imagetic, on the design process.

In the scope of the development of practice-based researches, what we find in Vieira's work is essentially a link between the design-based, historical and historiographic indicators in which the very construction of the "look at the object" is built intrinsically in the articulation between the historical and the design knowledge. Each one of the seven vias: context, occupation, permeability, sociability, flows, stratification and structure reflects, in its own denomination, meanings that unfold in two strands: the design meanings permeated with historically constructed values.

From the point of view of contributing to the broader practice-based research debate, this article also sought to corroborate the set of researches and publications that have reinforced the importance not only of the professional experience recognition regarding its relevance in academic studies on architecture design and history but also of the necessity to carrying out the debate on the ways in which the professional expertise can be effectively convened in the service of historical/ historiographic interpretations of architecture.

In the present article, a revision was made in the original use of the term in English, which seemed to give greater precision and fidelity of meaning to the original idea. Therefore, we opted for the adoption of the term "via" for the Portuguese and English versions, a possible and appropriate hypothesis in both cases and that, obvious as it may seem, was not evident at the time of the conclusion of that work.

\section{References}

BORDEN, I.; RAY, K. R. The Dissertation: an architecture student's handbook. Architectural Press, 2009.

CROSS, N. Designerly ways of knowing: design discipline versus design science. Design Issues, Volume 17, No. 3, 2001.

CROSS, N. Designerly ways of knowing. Design Studies, 3 (4): 221-227.

FOQUÉ, R. Building Knowledge in Architecture. Asp / Vubpress / Upa, 2010. 
LIMA, A. G. G.; BIGGS, M.; BÜCHLER, D. The Value of Architectural Sketches. Working Papers on Design, 4, ed. Grace Lees-Maffei. (Acesso em 04 de Junho de 2016).

LIMA, A. G. G.; BIGGS, M.; BÜCHLER, D. "Drawing about images: textual and non textual interpretation". Working Papers in Art and Design, 5, 2009. (Acesso em 04 de Junho de 2016).

LIMA, A. G. G.; ZEIN, R. V. Proyecto y Métodos proyectuales en La Investigación académica: algunos indicadores útiles. In: IV Jornadas Internacionales sobre Investigación en Arquitectura y Urbanismo, 2011, Valencia. Annales de las IV Jornadas Internacionales sobre Investigación en Arquitectura y Urbanismo. Valencia: General de Ediciones de Arquitectura, 2011.

LIMA, A. G. G.; SOUZA, C. L.; MEIRELLES, C.; CASTRO, L. G.; PISANI, M. A. J.; VILLAC, M. I.; MEDRANO, R. Proyectos, teorias e investigación: tendencias de la enseñanza en arquitectura y urbanismo. In: 100 years of teaching in architecture, 2011, Lima. Anais 100 years of teaching in architecture. Lima: Facultad de Arquitectura, Urbanismo y Artes - Universidad Nacional de Ingenieria, 2011.

LIMA, A. G. G.; BIGGS, M.; BÜCHLER, D.; PERRONE, R. A. C.; ZEIN, R. V. ; SANTOS, C.; VILLAC, M. I. BASTOS, M. A. Indicadores de Pesquisa Acadêmica em Áreas de Prática Projetual. In: V Projetar Processos de Projeto: Teorias e Práticas, 2011, Belo Horizonte. Anais do Congresso Projetar: Processos de Projeto:Teorias e Práticas. Belo Horizonte: Escola de Arquitetura da UFMG; NPGAU, 2011. V. 1.

LAWSON, B. Como Arquitetos e Designers pensam. São Paulo: Oficina dos textos, 2011.

LIMA, A. G. G.; PERRONE, R. A. C.; ZEIN, R. V.; SANTOS, C. R. dos; FAVARO, H. A.; BIGGS, M.; VIEIRA, J. L.; JÚNIOR, M. A. C. Práticas Projetuais: práticas de projeto de arquitetas, arquitetos e designers: análise dos instrumentos de prática projetual e possíveis empregos, de forma direta ou não - na pesquisa acadêmica stricto sensu. Disponível em: $<$ https://praticasprojetuais.wordpress.com/>.

MONTANER, J. M. As formas do século XX. Barcelona: Gustavo Gili, 2002.

NORBERG-SCHULZ, C. Existencia, Espacio y Arquitectura , Barcelona: Blume, 1975.

PERRONE, R. A. C.; LIMA, A. G. G; FLÓRIO, W. (2006) The sketches and the design process in architecture. Working Papers in Art and Design 4, 2006. (Acesso em 04 de Junho de 2016).

SCRIVENER, S. Reflection in and on action and practice in creative-production doctoral projects in art and design. Working Papers in Art and Design 1, 2000. (Acesso em 30 de Maio de 2016).

WAISMAN, M. El Interior de la Historia: Historiografia Arquitectonica para Uso de Latinoamericanos. Bogotá: Escala, 2009.

VIEIRA, J. L. Vias de aproximação para uma leitura da condição espacial na arquitetura. Tese de doutorado apresentada à Faculdade de Arquitetura e Urbanismo da Universidade de São Paulo. 2015. 